\title{
NON-DESTRUCTIVE QUALITY ASSESSMENT OF TOMATO FRUIT USING DIFFERENTIAL ABSORBANCE TECHNIQUE
}

\author{
M.A. Rahman ${ }^{*}$, , M.N. Islam1, T.A.A. Nasrin'1 and M.M. Begum² \\ Received 22 August 2019, Revised 5 December 2019, Accepted 24 December 2019, Published online 31 December 2019
}

\begin{abstract}
A rapid and non-destructive assessment of quality parameters in tomatoes was evaluated using a portable differential absorbance (DA) meter in order to accurately establish optimum harvest maturity. A commercial tomato variety cv. 'BARI Tomato-8' grown in the summer season of Bangladesh was used in this study. Different quality parameters including fruit skin colour, tissue firmness, chlorophyll contents, ascorbic acid, total soluble solids (TSS), titratable acidity and $\mathrm{pH}$ of tomatoes were determined using standard reference methods. Correlation analysis was performed to determine the relationship between the difference in absorbance index ( $\left.\mathrm{I}_{\mathrm{DA}}\right)$ and fruit quality parameters. The correlation coefficients showed good ability in estimating the hue angle, chlorophyll contents, titratable acidity and firmness of tomatoes showing ' $r$ ' values of $0.93,0.91,0.91$ and $0.92-0.94$, respectively. However, the changes of ascorbic acid contents and TSS of tomatoes did not follow the linear model during fruit maturation. Thus, the DA meter could most accurately predict the major quality attributes and may be used as an efficient technique for in-plant non-destructive assessment of tomato fruit qualities.
\end{abstract}

Keywords: Tomato, Differential Absorbance (DA), Maturity Index, Fruit Firmness, Skin Colour, Chlorophyll Contents.

\footnotetext{
${ }^{1}$ Horticulture Research Centre, BARI, Joydebpur, Gazipur-1701, Bangladesh.

${ }^{2}$ Tuber Crop Research Centre, BARI, Joydebpur, Gazipur-1701, Bangladesh.

*Corresponding author's email: dratiqbari@gmail.com (M.A. Rahman)
}

Cite this article as: Rahman, M.A., Islam, M.N., Nasrin, T.A.A. and Begum, M.M. 2019. Non-destructive quality assessment of tomato fruit using differential absorbance technique. Int. J. Agril. Res. Innov. Tech. 9(2): 4250. DOI: 10.3329/ijarit.v9i2.45409.

\section{Introduction}

Tomato (Solanum lycopersicum L.) is one of the most important crops grown extensively throughout the world especially in the temperate region. The crop is sensitive to environmental factors like temperature and solar radiation (Bhatt et al., 1999). However, nowadays, tomatoes are growing both in winter and summer season in Bangladesh.

Maturity is an integral component of produce quality particularly in the context of commercial maturity (Wills et al., 1998). Maturity index is the sign or indication of the readiness of fruits and vegetables for harvest according to the consumer's choice (Bautista and Esguerra, 1990). Generally, tomatoes are harvested at either the breaker-turning stage or ripe stage. However, precise determination of tomato maturity is difficult at harvest. Fruits are harvested at different degrees of maturity and a proportion of fruits may be immature. Thus, harvesting of fruits of different maturity at the same time is a common problem even though fruits may have the same skin colour at harvest (Tadesse et al., 2002). If fruits are picked at immature stage, they may stay green longer but may not develop acceptable colour and flavour upon ripening (Boonyakiat et al., 1987), which may lead to loss of consumer confidence. Over matured fruit, on the other hand, lose their attractiveness and crispiness and become slimy in texture within very short time (Pareek, 2001). Therefore, determining the optimum maturity will benefit both consumer and grower. Thus, there is a need to develop optimum maturity and quality indices for tomato that are objective and consistent more reliable than existing methods.

The maturity stage of tomato is normally determined based on destructive parameters such as flesh firmness, starch breakdown, levels of acidity and soluble solid content, on a small sample of fruit that may not fully represent of the variability within fruit batches. A non-destructive 
instrument, differential absorbance (DA) meter, on the other hand, was claimed to able to carry out measurements on much larger sample sizes with the added advantage of repeated analysis in time over the same samples to follow their physiological evolution. The DA meter measures the chlorophyll content in a fruit and, as a consequence, its state of maturity. This experiment was therefore conducted to assess a non-destructive measurement of tomato maturity and quality characteristics using a portable DA meter.

\section{Materials and Methods}

\section{Flower tagging and fruit harvest}

A popular commercial summer tomato variety cv. BARI Tomato-8 grown at the research field of Horticulture Research Centre, Bangladesh Agriculture Research Institute (BARI), Gazipur, Bangladesh was used in this experiment. Flowers were tagged on first day of fruit set to determine the stage of fruit development. Tomatoes were harvested at every alternate day started on 21 days after fruit set (DAFS) until 31 DAFS. Flowers were tagged on first day of fruit set to determine the stage of fruit development. Sixty randomly selected tagged fruits from different plants were harvested at each alternate day started on 21 days after fruit set (DAFS) until 31 DAFS to determine their physicochemical properties like tissue firmness, external colour, chlorophyll index using DA meter, TSS, ascorbic acid content and $\mathrm{pH}$.

\section{Measurements of surface colour}

Surface colour of tomato was measured with a Chroma Meter (Model CR-400, Minolta Corp., Japan). CIE $L^{*} a^{*} b^{*}$ coordinates were recorded using D65 illuminants and a $10^{\circ}$ Standard Observer as a reference system. $L^{*}$ is lightness, $a^{*}$ (-greenness to +redness) and $b^{*}$ (-blueness to +yellowness) are the chromaticity coordinates. The $a^{*}$ and $b^{*}$ values were converted to chroma $\left[C=\left(a^{*_{2}}+b^{*_{2}}\right)^{1 / 2}\right]$ and hue angle $\left[h=\tan ^{-1}\right.$ $\left.\left(b^{*} / a^{*}\right)\right]$. Before measurement, the equipment was calibrated against a standard white tile. Skin colour was measured at two opposite middle positions on the fruit surface using 20 fruits replicated thrice at each sampling period.

\section{Measurement of fruit firmness}

Firmness analysis was performed using both destructive method using Fruit Texture Analyzer (GUSS, Model No. GS25, SA supported by FTA Win Software) and a non-destructive firmness tester (53215 Fruit Hardness Tester, T.R. Turoni, Italy). With fruit texture analyzer, firmness measurement was taken as the maximum penetration force reached during the tissue breakage and determined with $8 \mathrm{~mm}$ diameter stainless steel flathead probe, which penetrates in a normal direction at a cross-head speed of $5 \mathrm{~mm}$ $\mathrm{s}^{-1}$. After establishing zero-force contact between the probe and the horizontally positioned fruit, specimens were compressed $3 \mathrm{~mm}$ at two equidistant points along with the equatorial region of each fruit. The maximum force generated during probe travel was used for data analysis. Results were expressed in Newton (N). In case of non-destructive method, fruit samples were horizontally placed under the firmness tester and pressed the probe for a moment. Data were taken from two equidistant points of each fruit and expressed in shore. Twenty tomato fruits replicated thrice were used at each sampling time for measuring the tissue firmness in each method.

\section{Measurement of absorbance difference index $\left(I_{A D}\right)$}

In this experiment, difference of absorbance index of tomato fruit was measured using DA Meter (tr DA Meter, T.R. Turoni, Italy). Fruits were harvested at every alternate day started on 21 DAFS and finished on 31 DAFS, from a preoptimum maturity stage until fruit were of red ripe stage of maturity. At each sampling period, DA readings were measured on both cheeks of 20 fruit, replicated 3 times. DA readings were correlated with chlorophyll content, TSS, titratable acidity, $\mathrm{pH}$ and vitamin $\mathrm{C}$ content as well as with non-destructive measurements of surface color using a colorimeter and firmness using a hardness tester.

\section{Measurements of ascorbic acid, titratable acidity (TA), total soluble solids (TSS) and pH}

Ascorbic acid content was estimated by 2,6dichlorophenolindophenol titration following the method by Ranganna (1986), and results were expressed as $\mathrm{mg}^{100 \mathrm{~g}^{-1}}$ fresh weight. Titratable acidity expressed as citric acid (\%) was determined by titration with $0.1 \mathrm{~mol} \mathrm{~L}^{-1} \mathrm{NaOH}$ to $\mathrm{pH} 8.1$ according to the method by Ranganna (1986). The total soluble solids and $\mathrm{pH}$ of the juice were determined by using hand-held refractometer (Model $\mathrm{N}-1 \mathrm{E}$, Brix $0-32 \%$, Atago, Japan, brix range $0-30 \%$ at $20^{\circ} \mathrm{C}$ ) and glass electrode $\mathrm{pH}$ meter (Microprocessor $\mathrm{pH}$ meter, Hanna Instruments), respectively.

\section{Measurement of chlorophyll content using acetone method}

The thin pericarp of the tomato was cut into small pieces with a sharp knife and put $2 \mathrm{~g}$ of fresh tissue into a mortar. Crush the tissue thoroughly with a pestle. Acetone (80\%) was added to allow the tissue to be thoroughly homogenized. Then the supernatant was decanted through a filter paper into a $100 \mathrm{ml}$ volumetric flask. The 
extraction procedure was repeated by adding $80 \%$ acetone to the mortar. Finally, the volume was made up to $100 \mathrm{ml}$ with $80 \%$ acetone and measures the chlorophyll content using spectrophotometer (T80 UV/VIS Spectrophotometer, PG Instrument Ltd.) at 645 and $663 \mathrm{~nm}$ (Whitam et al., 1986). Final result in chlorophyll contents were expressed in $\mu \mathrm{g} \mathrm{g}^{-1}$. Chlorophyll content (mg g-1) was calculated using the following formula:

Chlorophyll $(\mathrm{a}+\mathrm{b})=\left[20.2\left(\mathrm{OD}_{645}\right)+8.02\right.$ $\left.\left(\mathrm{OD}_{663}\right)\right] \mathrm{x} \mathrm{V} / 1000 \mathrm{~W}$

Where,

$\mathrm{V}=$ Final volume (ml) of acetone-chlorophyll extract

$\mathrm{W}=$ Fresh weight $(\mathrm{g})$ of plant sample

\section{Statistical analysis}

The data were subjected to analysis of variance (ANOVA) using the ' $R$ Statistical Software version 3.1.2. The results showing significant differences were then subjected to mean separation using LSD test at $P<0.05$.

\section{Results and Discussion}

\section{Measurement of fruit surface colour}

Surface colour changes of tomato fruits were monitored by measuring lightness $\left(\mathrm{L}^{*}\right)$ and hue angle $\left(\mathrm{h}^{\circ}\right)$ during harvesting periods. Values are presented in Table 1. The intensity of green colour of fruit skin was slowly decreased with extend the harvesting time and turned to breaker, pink and finally red as evidenced by decreasing values of $L^{*}$. The initial values of $L^{*}$ was 68.5 recorded in premature fruits harvested after 21days of fruit set (DAFS), which gradually decreased with increased in harvesting time and reached to minimum level of 38.5 in red ripe fruit harvested at 31 DAFS indicating dark in surface colour. Tomatoes harvested at different maturity stages showed significant differences in lightness of surface colour.

Hue angle is an indicator of colour change from green to yellow and red. In this study, the degree of hue angle was recorded 125.2 in premature fruit surface that harvested after 21 DAFS (Table 1). After that fruit showed a significant decrease in hue angle with extent the harvest period and attained the minimum level of 53.7 after 31 DAFS indicating complete red in colour. This fall in hue value indicated that the intensity of green colour slowly decreased with maturity and turned to red. The colour changes in tomato correspond to a decrease in chlorophyll and an increase in carotenoid synthesis (Pretel et al., 1995). Findings of this study are in agreement with Tadesse et al. (2002), who reported that the hue angle of capsicum fruits (cv. Domono) decreased sharply after seven weeks of anthesis that reflecting the colour change from green to red.

Table 1. Changes of skin colour, fruit firmness and DA Index of tomatoes cv. BARI Tomato- 8 at different maturity stages during summer season.

\begin{tabular}{|c|c|c|c|c|c|c|}
\hline Days to harvest & Maturity stage & $\mathrm{L}^{*}$ & $\mathrm{~h}^{\circ}$ & $\begin{array}{c}\text { Firmness } \\
\text { (Shore) }\end{array}$ & $\begin{array}{l}\text { Firmness } \\
(\mathrm{N})\end{array}$ & $\begin{array}{l}\text { DA Index } \\
\text { (IDA) }\end{array}$ \\
\hline 21 DAFS & Pre-mature green & $68.5 \mathrm{a}$ & $125.2 \mathrm{a}$ & $94.0 \mathrm{a}$ & $18.4 \mathrm{a}$ & $1.05 \mathrm{a}$ \\
\hline 23 DAFS & Mature Green & $60.2 \mathrm{~b}$ & $117.7 \mathrm{~b}$ & $88.0 \mathrm{~b}$ & $15.1 \mathrm{~b}$ & $0.82 \mathrm{~b}$ \\
\hline 25 DAFS & Breaker-turning & $55.1 \mathrm{c}$ & $108.5 \mathrm{c}$ & $84.7 \mathrm{c}$ & $12.0 \mathrm{c}$ & $0.62 \mathrm{c}$ \\
\hline 27 DAFS & Pink & $53.0 \mathrm{~cd}$ & $97.7 d$ & $73.0 \mathrm{~d}$ & $10.2 \mathrm{~d}$ & $0.55 \mathrm{~d}$ \\
\hline 29 DAFS & Light red & $50.0 \mathrm{~d}$ & $77.7 \mathrm{e}$ & $60.0 \mathrm{e}$ & $6.5 \mathrm{e}$ & $0.00 \mathrm{e}$ \\
\hline 31 DAFS & Red & $38.5 \mathrm{e}$ & $53.7 f$ & $52.2 \mathrm{f}$ & $6.0 \mathrm{e}$ & $0.00 \mathrm{e}$ \\
\hline Probability & & * & $* *$ & $* *$ & $* *$ & $* *$ \\
\hline CV (\%) & & 3.4 & 4.1 & $7 \cdot 5$ & 12.1 & 11.0 \\
\hline
\end{tabular}

DAFS = Days after fruit set; $L^{*}=$ Lightness; $h^{\circ}=$ Hue angle.

${ }^{*}=$ Significant at $0.05 ;{ }^{* *}=$ Significant at 0.01 .

Values within a column not followed by a common letter are significantly different.

\section{Measurement of fruit firmness}

Tissue firmness is a critical quality attribute in the consumer acceptability of fresh fruits and vegetables. The maximum firmness of $18.4 \mathrm{~N}$ or 94 shore was recorded in premature tomatoes harvested at 21 DAFS (Table 1), which progressively decreased with extend the harvesting time from fruit set and reached the minimum level of $6 \mathrm{~N}$ after 31 DAFS. Both destructive and non-destructive method of tissue firmness measurement showed similar trend in decreasing firmness with increased in harvesting time. Significantly, the lowest value of fruit firmness was recorded in red ripe tomato compared to other stages of maturity. Generally, the firmness of tomato fruit showed a decreasing trend during maturation to ripening (Rahman et al., 2014), which might be due the production and action of ethylene in the fruit at ripening stages (Choi and Huber, 2008; Dong et al., 2002; Mathur and Srivastava, 2005). 


\section{Measurement of absorbance difference index $\left(I_{A D}\right)$}

Statistical differences were found regarding the $\mathrm{I}_{\mathrm{AD}}$ among tomato fruits harvested at different maturity stages (Table 1). The highest $\mathrm{I}_{\mathrm{DA}}$, which indicated the maximum chlorophyll content was 1.05 at pre-optimum mature tomato harvested at 21 DAFS, which declined gradually exhibiting the lowest IDA of 0.55 in fruits of pink stage harvested at 27 DAFS. The IDA became zero in light red and red ripe tomatoes harvested at 29 and 31 DAFS, respectively.

\section{Measurement of chlorophyll content}

A wide variation in chlorophyll content of tomatoes was found at different maturity stages of fruits. The highest chlorophyll content of 14.5 $\mu \mathrm{g} \mathrm{g}^{-1}$ was found in pre-optimum mature green tomato harvested at 21 DAFS (Table 2). After that, the chlorophyll content was gradually decreased with lengthening the harvesting time reaching the lowest level of $0.5 \mu \mathrm{g} \mathrm{g}^{-1}$ in light red tomatoes harvested at 29 DAFS. The red ripe tomato, however, did not contain chlorophyll anymore. Almost similar trend in decreasing the chlorophyll content of tomato during maturation was also found by Watada et al. (1976) who reported that the average chlorophyll content decreased from $13.4 \mu \mathrm{g} \mathrm{g} \mathrm{g}^{-1}$ fresh weight in immature-green fruit to $0.3 \mu \mathrm{g} \mathrm{g}^{-1}$ fresh weight in partially ripe tomato (cv. Walter).

\section{Measurement of ascorbic acid, TSS, pH and $T A$}

It is evident that the length of harvesting time induced significant variation in ascorbic acid content of tomato fruits (Table 2). The ascorbic acid content was fair (13.9 mg $\left.100 \mathrm{~g}^{-1}\right)$ in premature fruits harvested at 21 DAFS, gradually increased thereafter until 25 DAFS showing the maximum value of $19.9 \mathrm{mg}^{100 \mathrm{~g}^{-1}}$ in breakerturning tomato. There was no statistical difference $(P \leq 0.05)$ in regards of ascorbic acid content in mature green and breaker-turning tomatoes harvested at 23 and 25 DAFS, respectively. After 25 DAFS the content of ascorbic acid slowly declined and reached the minimum level of $13.7 \mathrm{mg}^{100 \mathrm{O}^{-1}}$ in red ripe fruit. The results are in agreement with Lee and Kader (2000) who reported that the losses of ascorbic acid can be continued through maturity, postharvest handling, processing, cooking, and storage of fruits and vegetables.

Table 2. Changes of chlorophyll contents, ascorbic acid, TSS, $\mathrm{pH}$ and titratable acidity of tomatoes cv. BARI Tomato- 8 at different stages of maturity during summer season.

\begin{tabular}{|c|c|c|c|c|c|c|}
\hline $\begin{array}{l}\text { Days to } \\
\text { harvest }\end{array}$ & Maturity stage & $\begin{array}{c}\text { Total } \\
\text { chlorophyll } \\
\left(\mu \mathrm{g} \mathrm{g}^{-1}\right)\end{array}$ & 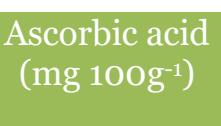 & TSS (\%) & $\mathrm{pH}$ & $\begin{array}{l}\text { TA } \\
(\%)\end{array}$ \\
\hline 21 DAFS & Pre-mature green & $14.5 \mathrm{a}$ & $13.9 \mathrm{~d}$ & $3.75 \mathrm{~d}$ & $4.72 \mathrm{a}$ & $0.51 \mathrm{~d}$ \\
\hline 23 DAFS & Mature Green & $11.2 \mathrm{~b}$ & $18.7 \mathrm{ab}$ & $4.11 \mathrm{~b}$ & $4.43 \mathrm{~b}$ & $0.51 \mathrm{~d}$ \\
\hline 25 DAFS & Breaker-turning & $5.7 \mathrm{c}$ & $19.9 \mathrm{a}$ & $4.32 \mathrm{a}$ & $4.11 \mathrm{c}$ & $0.52 \mathrm{c}$ \\
\hline 27 DAFS & Pink & $2.4 \mathrm{~d}$ & $17.7 \mathrm{~b}$ & $4.25 \mathrm{ab}$ & $4.03 \mathrm{~d}$ & $0.58 \mathrm{~b}$ \\
\hline 29 DAFS & Light red & $0.5 \mathrm{e}$ & $14.3 \mathrm{c}$ & $4.12 \mathrm{~b}$ & $3.94 \mathrm{e}$ & $0.61 \mathrm{ab}$ \\
\hline 31 DAFS & Red & $0.0 \mathrm{f}$ & $13.7 \mathrm{~d}$ & $4.02 \mathrm{c}$ & $3.90 \mathrm{e}$ & $0.64 \mathrm{a}$ \\
\hline Probability & & $* *$ & $* *$ & $*$ & * & $*$ \\
\hline CV (\%) & & 2.6 & 1.95 & 2.4 & 0.56 & 2.3 \\
\hline
\end{tabular}

DAFS = Days after fruit set; * Significant at $0.05 ;{ }^{* * *=S i g n i f i c a n t ~ a t ~} 0.01$.

Values within a column not followed by a common letter are significantly different.

The changes in TSS content of tomato fruits with harvesting length is presented in Table 2. The lowest TSS of $3.75 \%$ was found in younger fruit harvested at 21 DAFS, which slowly increased and reached the maximum level of $4.32 \%$ in breakerturning tomatoes harvested at 25 DAFS and declined thereafter. No significant difference $(P \leq 0.05)$ regarding the TSS content was observed in fruits harvested between 25 and 27 DAFS. The increase in TSS of tomato till breaker-turning stage of maturity was probably a result of increased in hexose sugar accumulation during fruit maturity as there is a close positive correlation between the rise in TSS and soluble sugars (Mendlinger et al., 1992).
The changes in $\mathrm{pH}$ of tomatoes as a function of different harvesting time are shown in Table 2. The highest $\mathrm{pH}$ of 4.72 was recorded in premature fruits harvested at 21 DAFS, which gradually decreased with extending the harvesting time showing the minimum value 3.9 in red ripe fruits harvested at 31 DAFS. Significant differences were observed in $\mathrm{pH}$ levels of tomatoes at different maturity stages. The titratable acidity, on the other hand showed the lower values (0.51-0.52\%) in fruits harvested from 21 to 25 DAFS, increased significantly thereafter reaching the highest level of $0.64 \%$ in red ripe fruit harvested at 31 DAFS. 

Correlation between $I_{D A}$ and quality
attributes of tomatoes

Correlation between DA meter readings and different quality parameters of tomato are presented in Figures 1-8. During harvest, the DA meter could most accurately predict flesh firmness, hue angle of skin colour, chlorophyll content and TA showing the ' $r$ ' values of $0.92-$ $0.94,0.93,0.91$ and 0.91 , respectively indicating high correlation between I $\mathrm{DA}_{\mathrm{DA}}$ and those quality attributes. The findings are in agreement with Rathna et al. (2015), who found high correlation between IDA and firmness, hue angle (skin colour) and TA contents of different advanced tomato lines/variety. Significant correlation coefficients were also noted between $\mathrm{I}_{\mathrm{DA}}$ and lightness of skin colour and $\mathrm{pH}$ exhibiting the ' $r$ ' values of 0.87 and 0.87 , respectively.

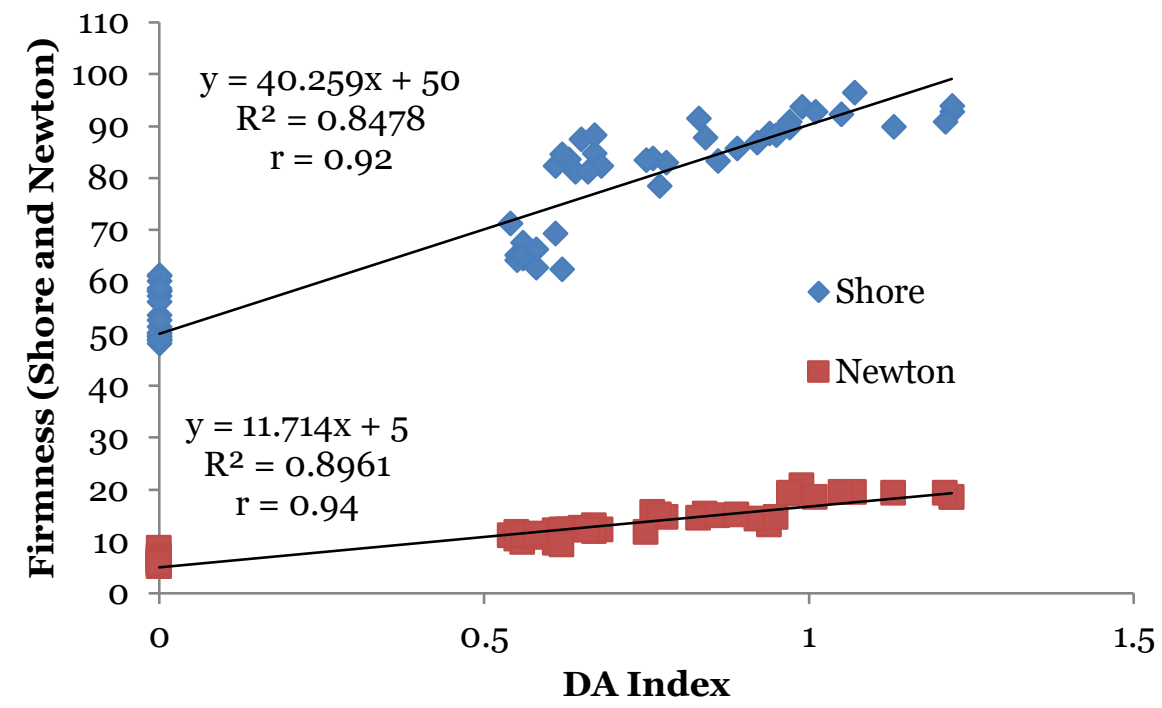

Figure 1. Correlation between $I_{D A}$ and corresponding flesh firmness measurements (both nondestructive and destructive) for BARI Tomato-8 harvested at different maturity stages.

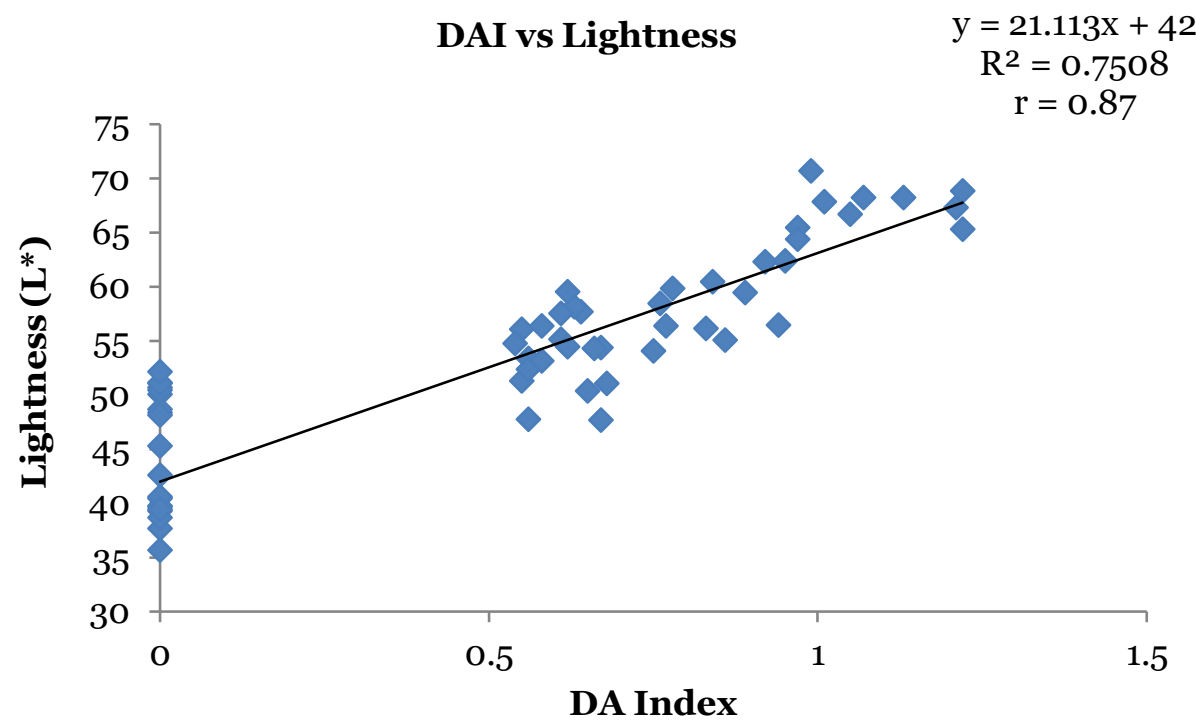

Figure 2. Correlation between $I_{D A}$ and corresponding lightness measurements of skin colour for BARI Tomato-8 harvested at different maturity stages. 


\section{DAI vs hue angle}

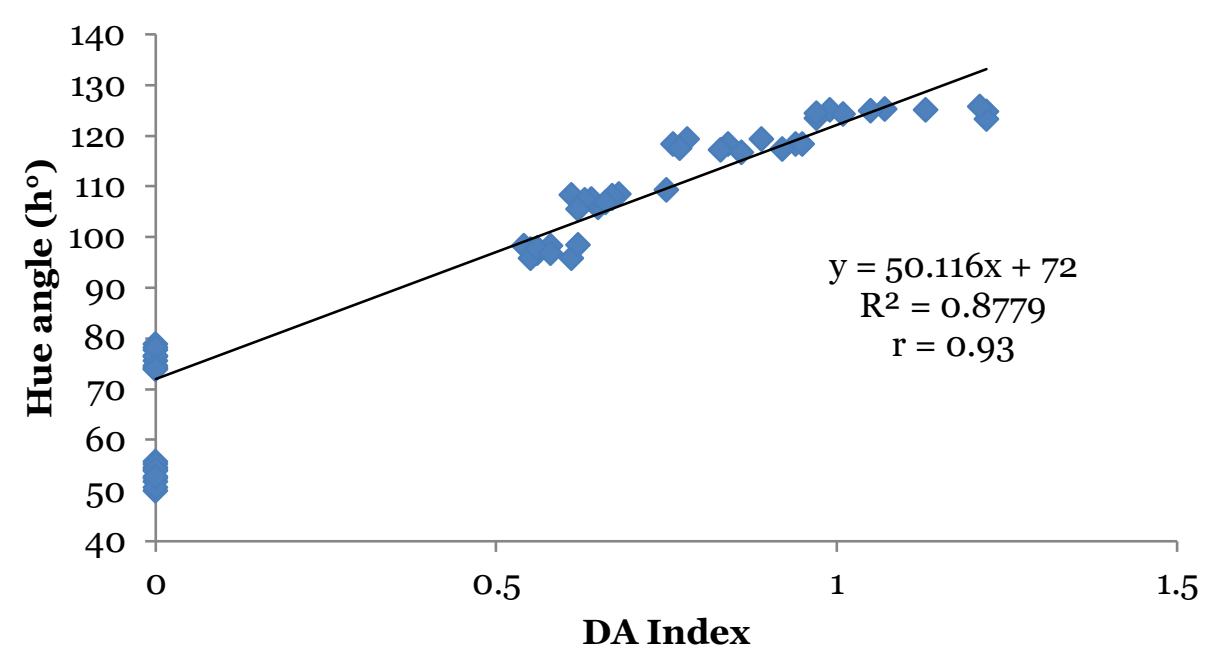

Figure 3. Correlation between IDA and corresponding hue angle measurements of skin colour for BARI Tomato-8 harvested at different maturity stages.

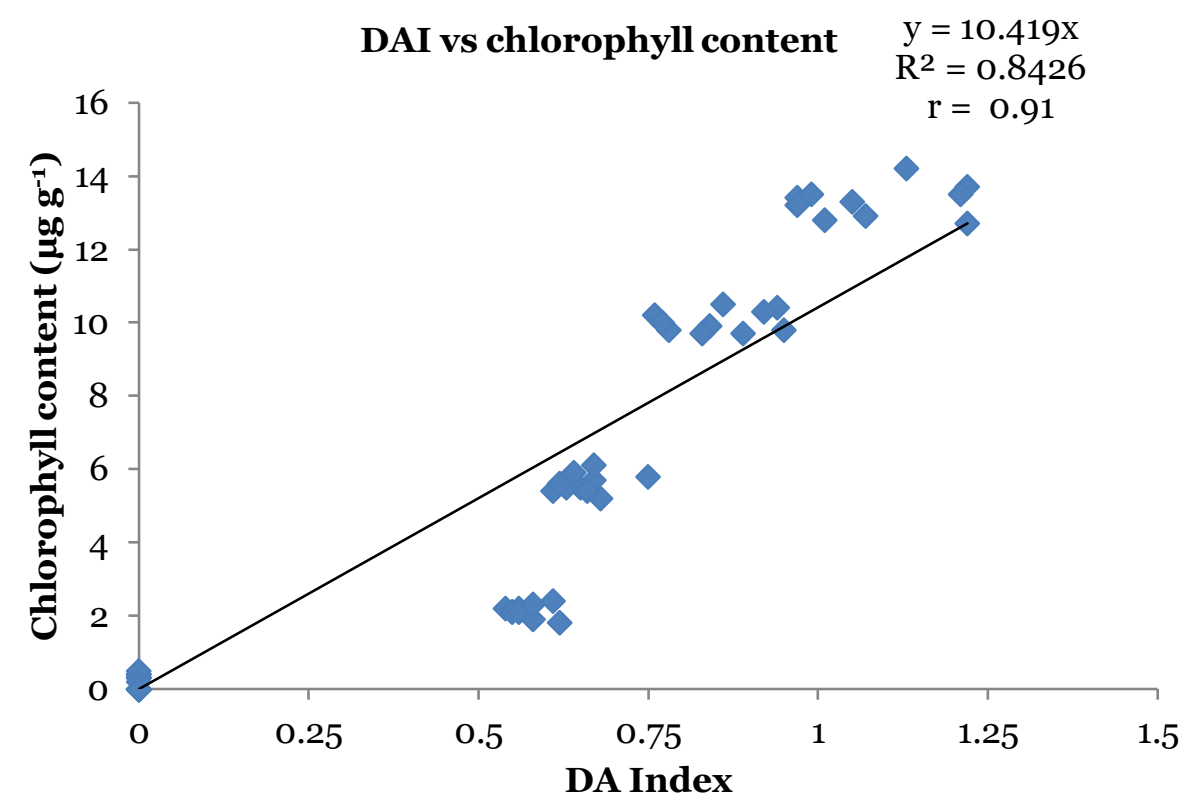

Figure 4. Correlation between IDA and corresponding chlorophyll contents of fruit pericarp for BARI Tomato-8 harvested at different maturity stages. 
Rahman et al. (2019) Non-destructive quality assessment of tomato fruit using absorbance technique

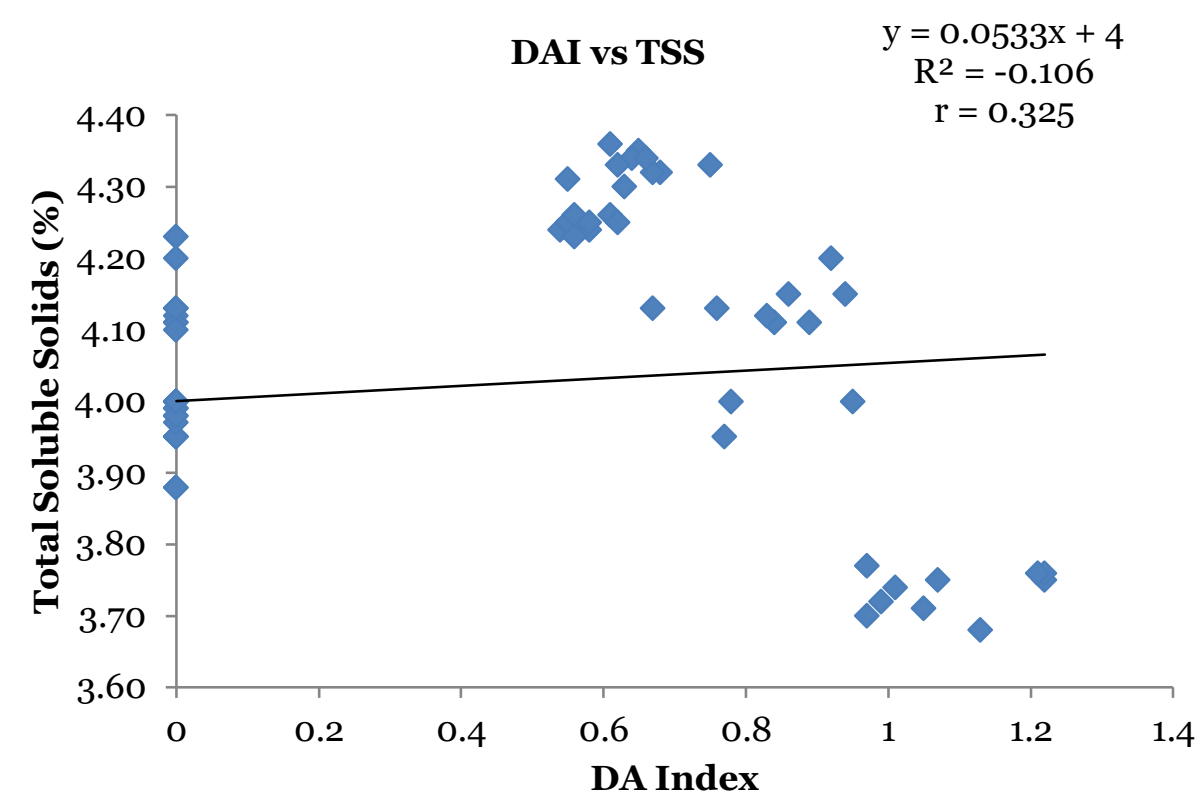

Figure 5. Correlation between IDA and corresponding fruit TSS contents for BARI Tomato-8 harvested at different maturity stages.

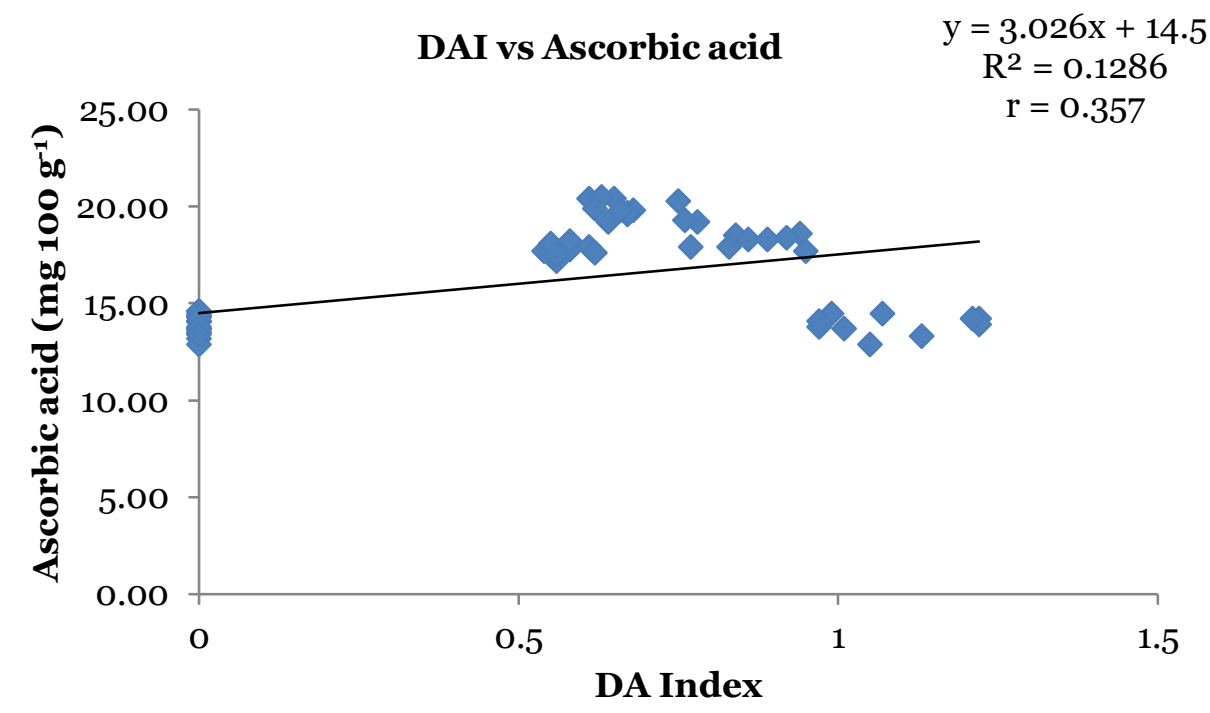

Figure 6. Correlation between IDA and corresponding ascorbic acid contents for BARI Tomato-8 harvested at different maturity stages. 


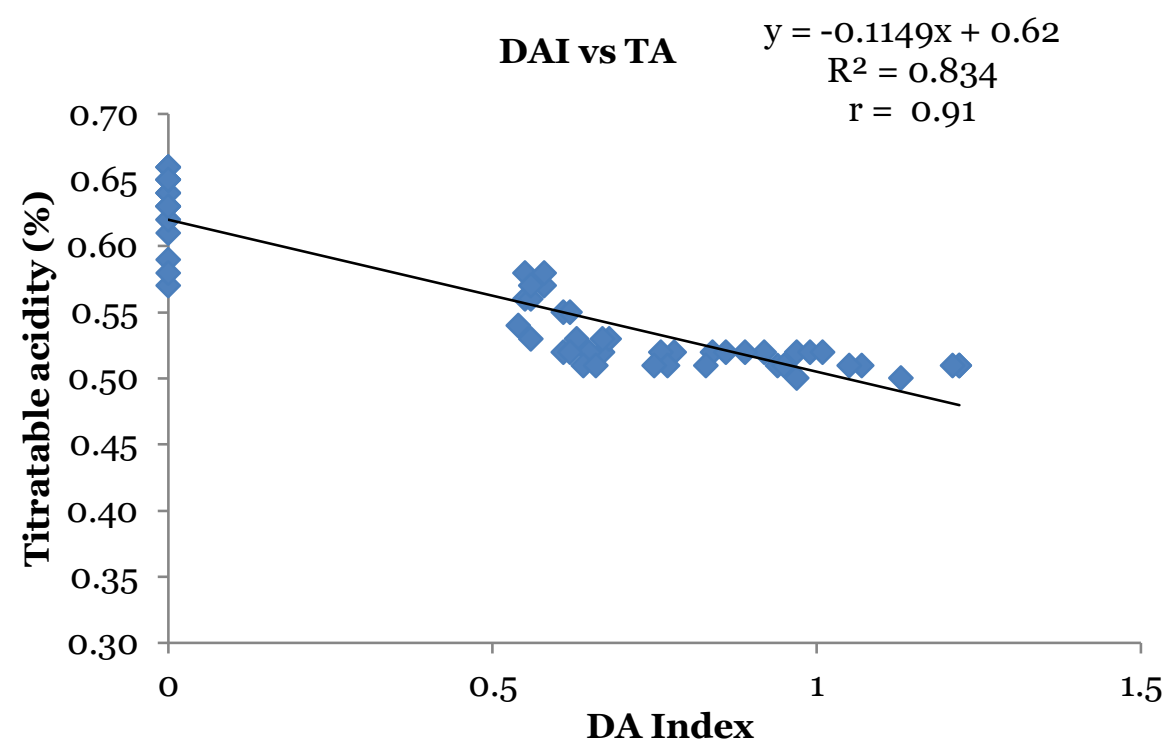

Figure 7. Correlation between IDA and corresponding titratable acidity (TA) for BARI Tomato-8 harvested at different maturity stages.

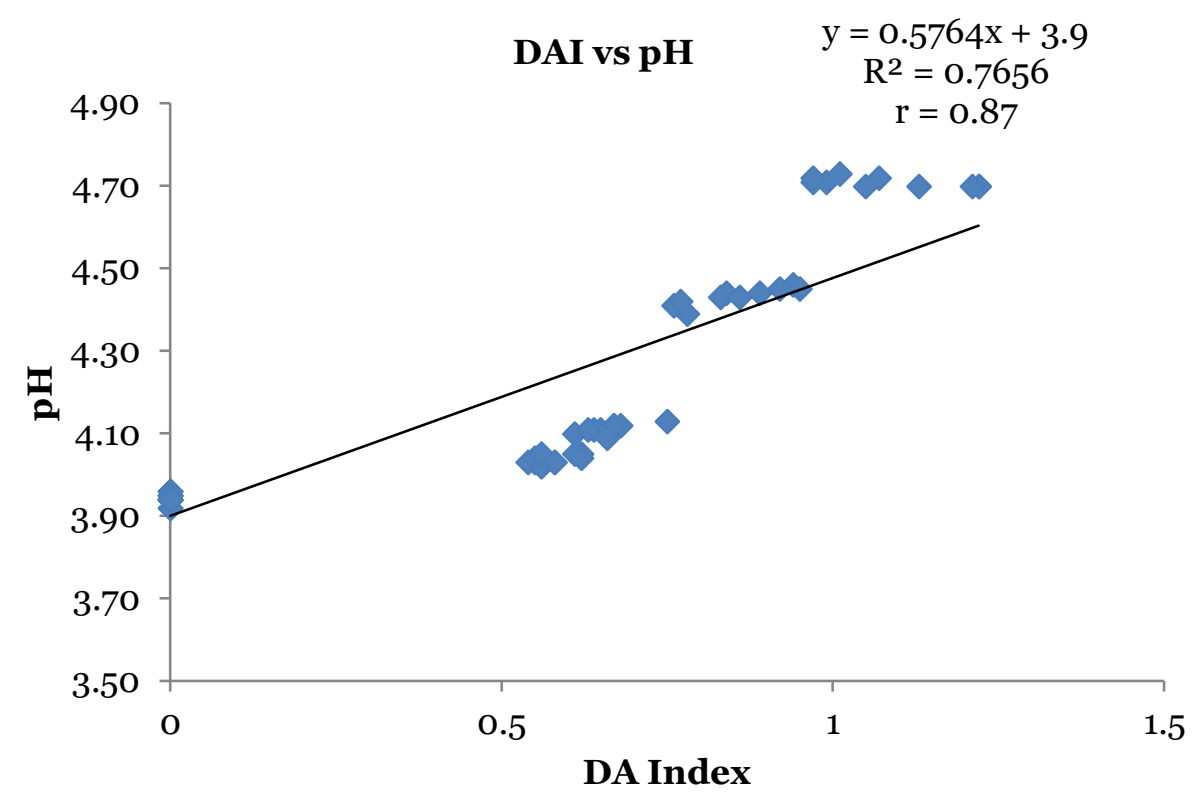

Figure 8. Correlation between $\mathrm{I}_{\mathrm{DA}}$ and corresponding $\mathrm{pH}$ level for BARI Tomato-8 harvested at different maturity stages.

The lower correlations of these parameters compared to flesh firmness or hue angle was because of the changes in lightness and $\mathrm{pH}$ over the harvesting period was not as pronounced as the hue angle or firmness changed. Correlation analysis for comparing the IDA with ascorbic acid and soluble solid resulted in very low ' $r$ ' values ( 0.357 and 0.325 , respectively) indicating little or no correlation. This was because the trend of changes of these nutrients was not linear during different phases of maturation in tomatoes, especially when compared to flesh firmness and hue angle. The results indicate the potential of the DA meter in measuring most quality parameters non-destructively in tomato.

\section{Conclusion}

Results of the present study revealed that the DA meter is an effective device in assessing tomato harvest maturity as strong correlations was found for flesh firmness, chlorophyll content, skin colour and TA content in BARI Tomato-8. This meter easily separated green, breaker-turning, pink and red tomatoes into consistent classes, which have strong correlations with ethylene production rate, ripening behavior and consumer acceptance. Therefore, the DA meter may be a reliable and useful tool for measuring on-plant tomato maturity to establish the optimum harvest time to maximize postharvest life and quality. 


\section{Acknowledgements}

The authors gratefully acknowledge the Bureau for Food Security, U.S. Agency for International Development (USAID) for providing financial support for conducting this study under the World Veg/USAID Postharvest Program (Award No. AID-BFS-IO-12-00004).

\section{References}

Bautista, O.K. and Esguerra, E.B. 1990. Postharvest Technology for Southeast Asian Perishable Crops. Postharvest Horticulture Training and Research Centre, UPLB, College Laguna, Philippines. 447p.

Bhatt, R.M., Srubuvasa, R.N.K. and Anand, N. 1999. Response of bell pepper to irradiance photosynthesis, reproductive attributes and yield. Indian J. Hort. 56(1): 62-66.

Boonyakiat, D., Chen, P.M., Spotts, R.A. and Richardson, D.G. 1987. Effect of harvest maturity on decay and postharvest life of ' $\mathrm{d}$ ' Anjou' pear. Scientia Hortic. 31: 131-139.

Choi, S.T. and Huber, D.J. 2008. Influence aqueous 1-methylcyclopropene concentrations, immersion duration, and solution longevity on the postharvest ripening of breaker-turning tomato (Solanum lycopersicum L.) fruit. Postharvest Biol. Tech. 49(1): 147-154.

Dong, L., Lurie, S. and Zhou, H. 2002. Effect of 1methylcyclopropene on ripening of 'Canino' apricots and 'Royal Zee' plums. Postharvest Biol. Tech. 24(2): 135-145.

Lee, S.K. and Kader, A.A. 2000. Preharvest and postharvest factors influencing vitamin $\mathrm{C}$ content of horticulture crops. Postharvest Biol. Tech. 20: 207-220.

Mathur, K. and Srivastava, G.C. 2005. Effect of 1MCP on malic enzyme activity and ethylene production in mango during ripening. Indian J. Plant Physiol. 10(3): 273-275.

Mendlinger, S., Benzioni, A., Huyskens, S. and Ventura, M. 1992. Fruit development and postharvest physiology of Cucumis metuliferus Mey, a new crop plant. J. Hort. Sci. 67(4): 489-493.

Pareek, O.P. 2001. Ber. International Centre for Under-utilized Crops, Southampton, SO17 IBJ, UK. 290p.
Pretel, M.T., Serrano, M., Amoros, A., Riquelme, F. and Romojaro, F. 1995. Non-involvement of ACC and ACC oxidase activity on pepper fruit ripening. Postharvest Biol. Tech. 5(4): 295-302.

Rahman, M.A, Islam, M.N., Hossain, M.A., Begum, M.M. and Banu, S.P. 2014. Effect of aqueous 1-methylcyclopropene in delaying postharvest ripening of breaker-turning tomato fruit. Int. J. Postharvest Tech. Innov. 4(2/3/4): 208-220.

Ranganna, S. 1986. Handbook of Analysis and Quality Control for Fruit and Vegetable Products. 2nd ed. Tata McGraw-Hill, New Delhi, India. 1112p.

Rathna, N., Buntong, B., Rahman, A., Goffar, M.A., Pal, M.A., Acedo, Jr. A., Easdown, W., Hughes, J.A. and Keatinge, J.D.H. 2015. Non-invasive Quality Evaluation of Tomato Using Differential Absorbance: Trials in Cambodia, Bangladesh and India. P.70. In: Technical Programme and Book of Abstracts. $3^{\text {rd }}$ ISHS Southeast Asia Symposium on Quality Management in Postharvest Systems (SEAsia2015), 13-15 August 2015, Apsara Angkor Resort and Conference Center Siem Reap, Cambodia.

Tadesse, T., Hewett, E.W., Nichols, M.A. and Fisher, K.J. 2002. Changes in physicochemical attributes of sweet pepper cv. Domino during fruit growth and development. Sci. Hortic. 93: 91-103.

Watada, A.E., Norris, K.H., Worthing, J.T. and Massie, D.R. 1976. Estimation of chlorophyll and carotenoid contents of whole tomato by light absorbance technique. J. Food Sci. 41: 329-332.

Whitam, F.A., Blaydes, D.F. and Devlin, R.M. 1986. Chlorophyll absorption spectrum and quantitative determination. In: Exercise in plant physiology. PWS Publishers, Boston. pp. 128-131.

Wills, R., McGlasson, B., Graham, D. and Joyce, A.D. 1998. Postharvest Handling of fruit, Vegetables and Ornamentals. $\mathrm{CAB}$ International, Wallingford, OXON, OX1O DE, UK. 28op. 